\title{
KONTRIBUSI KAMPUNG BACA ASURANSI JASINDO DALAM MEMENUHI KEBUTUHAN LITERASI INFORMASI MASYARAKAT DI TAMAN SANDIK
}

\author{
Iwin Ardyawin
}

D3 Perpustakaan, Fakultas Ilmu Sosial dan Ilmu Politik, Universitas Muhammadiyah Mataram, e-mail iwinardyawin@gmail.com

\section{Rahmad Hidayat}

Fakultas Ilmu Sosial dan Ilmu Politik Universitas Muhammadiyah Mataram rahmad_dayat22@yahoo.com

\section{Cut Afrina}

Ilmu Perpustakaan dan Informasi Islam, Ushuluddin Adab dan Dakwah, Institut Agama Islam Negeri Batusangkar e-mail cutafrina@iainbatusangkar.ac.id

Received : 18 September 2021 Revised : 02 October 2021 Accepted : 20 October 2021 DOI

\begin{abstract}
This study discusses the contribution of the Jasindo Insurance Reading Village in Meeting the Information Literacy Needs of the Society in Sandik Park, Sandik Village, Gunungsari District, West Lombok Regency. The purpose of this study is to find out how the contribution of the reading village of Asuransi Jasindo in meeting the information literacy needs of the community in Taman Sandik and to find out how the obstacles in meeting the information literacy needs of the community in Taman Sandik are. The method used in this research is quantitative with descriptive research type. Data collection techniques used are interviews, observation and documentation. The data analysis technique used is the flow model analysis technique (flow model). To support this research, there are seven research steps used by researchers, namely (1) preparing a research design (2) Selecting a research field (3) Managing licensing (4) Exploring and assessing the field (5) Selecting and utilizing informants (6) Preparing research equipment (7) Research ethics issues. The contribution of Kampung Baca Asuransi Jasindo as a learning resource in Sandik Village is to become a learning platform that seeks to provide various learning and information sources, both in the form of library materials, novels, folklore books and other multimedia materials to the wider community regardless of status, age, and profession. The forms of contribution from the Jasindo Insurance Reading Village as a learning resource in Sandik Village include making an "Information Literacy" program, where the activity contains activities that are to introduce the community to using reading materials in Jasindo Insurance Reading Village.
\end{abstract}

Keywords: Information needs, Reading Village.

\section{PENDAHULUAN}

Keberadaan kampung baca asuransi jasindo terbilang masih baru terbukti dengan diresmikan pada bulan Mei 2019 oleh PT. Asuransi Jasa Indonesia di Desa Sandik, Kecamatan Batulayar Kabupaten Lombok Barat Provinsi Nusa Tenggara Barat dalam rangka memenuhi kebutuhan informasi masyarakat sehingga kedepan dapat berkontribusi dalam meningkatkan minat baca masyarakat. Kampung baca harus berperan aktif dalam memberikan informasi kepada masyarakat sehingga dampak dari informasi yang update 
setiap waktu, dapat memberikan solusi terhadap apa yang menjadi permasalahan yang ada di tengah masyarakat disitulah Kampung baca asuransi jasindo harus memberikan peran yang sangat penting sebagai solusi dari apa yang menjadi permasalahan tersebut. Kampung baca asuransi jasindo yang berada di tengah-tengah masyarakat harus mampu memberikan perannya sebagai penyedia informasi untuk memenuhi kebutuhan masyarakat. Kampung baca asuransi jasindo juga dituntut untuk dapat menyediakan pelayanan yang maksimal secara tepat dan cepat sesuai masing-masing kebutuhan masyarakat.

Dinamika media informasi yang berkembang mempengaruhi pula perkembangan minat masyarakat dalam mengakses informasi jika dahulu buku dan catatan-catatan manual menjadi sumber baca, maka kini sudah mengarah pada data online yang bisa diakses di semua tempat dan setiap saat. Wiji Suwarno (2016: 83). Kampung baca asuransi jasindo sangat dibutuhkan oleh masyaraklat dalam memenuhi kebutuhan informasi sehingga kedepan berbagai macam kegiatan yang bersifat menambah pengetahuan seperti meminjam buku, membaca ataupun mencari berbagai macam informasi yang ingin diketahui. Pelayanan merupakan ujung tombak, karena bagian inilah yang pertama berhubungan dengan masyarakat pengguna yang ada taman sandik, karena Kampung baca asuransi jasindobaru terasa manfaatnya bila informasi yang diberikan sesuai dengan kebutuhan masyarakat pengguna.

Fakta sudah terlalu jelas mengatakan bahwa wajah sebuah bangsa dapat dilihat dari wajah perpustakaannya dan kemajuan sebuah bangsa dapat dilihat dari tingkat minat bacanya. Baik secara langsung maupun tidak langsung kebiasaan membaca menjadi salah satu indicator kualitas sekolah bahkan secara nasional sangat menentukan tinggi rendahnya index pembangunan manusia atau human development index (HDI, dan tinggi rendahnya HDI menentukan kualitas bangsa. Sejarah dari kemajuan negara-negara di dunia, seperti Jepang, Amerika, Korea, dan negara-negara lainnya berawal dari ketekunannya membaca. Suherman (2011: 8). Keberhasilan Kampung baca asuransi jasindo sangat ditentukan oleh pelayanan yang maksimal ketika masyarakat berada diruangan baca merasa betah untuk berlama-lama.

Minat baca muncul ketika seseorang telah memiliki kemampuan membaca sedangkan budaya baca terpelihara bila bahan baca terjangkau dan jenis yang tersedia sesuai dengan minat pembacanya. Budaya baca dapat terwujud baik karena keinginan pribadi maupun bentukan lingkungan yang kondusif. Purwono (2013: 42-42). Masyarakat lebih memilih untuk searcing informasi di internet, sehingga keberadaan perpustakaan di tengah masyarakat menjadi terabaikan karena informasi yang mereka dapatkan belum terpenuhi. Dalam meningkatkan kebiasaan membaca masyarakat perlu adanya fasilitas dan koleksi yang 
dapat memenuhi kebutuhan informasi masyarakat. Kampung baca asuransi jasindo harus dapat melihat kebutuhan masyarakat sehingga dapat dengan leluasa memilih jenis bacaan mana saja yang dibutuhkan. Kampung baca asuransi jasindo memiliki koleksi yang sangat beragam, mulai dari anak-anak sampai orang tua yang berusia lanjut dapat memilih kebutuhan informasinya. Masyarakatpun terdiri dari berbagai macam profesi atau berbagai macam pendidikan, untuk itu kebutuhan informasi yang dicarinya juga sangat beragam dan berbeda-beda. Ini merupakan sebuah tantangan bagi Kampung Baca Asuransi Jasindo, untuk dapat memfasilitasi dan melengkapi semua jenis koleksi dan informasi yang dibutuhkan oleh masyarakat untuk meningkatkan minat baca semua lapisan masyarakat. Sehingga penelitian ini difokuskan pada bagaimana kontribusi yang dilakukan Kampung Baca Asuransi Jasindo dalam memenuhi kebutuhan literasi informasi masyarakat Di Desa Sandik Lombok Barat.

Tidak banyak kaum pelajar dari berbagai sekolah ataupun kampus lain yang berkunjung, begitupun dari masyarakat umum lainnya. Disebabkan hampir setiap sekolah ataupun kampus-kampus telah mempunyai perpustakaan sendiri-sendiri, ditambah dengan adanya pengaruh dari teknologi membuat masyarakat semakin malas untuk berkunjung ke perpustakaan ataupun ke kampung baca masyarakat untuk memenuhi kebutuhan literasi informasinya.

Dari segi fasilitas dan pelayanan yakni yang disediakan berupa buku-buku bacaan, komputer, wifi, dan ruangan yang telah di desain bertuliskan berbagai kata-kata, kalimat serta gambar yang kreatif, agar pengunjung lebih berminat berkunjung kembali untuk membaca. Terasa lengkap dengan pelayanan yang di berikan oleh pengelola, dengan konsep kombinasi antara taman bacaan masyarakat dan tempat bermain, pengunjung yang datang bisa membaca sambil menikmati berbagai jenis permainan yang telah disediakan. Hal tersebut juga dilakukan agar membuat ketertarikan pengunjung untuk berkunjung kembali.

Namun sampai saat ini konsep TBM literasi informasi yang telah di jalankan sudah lebih dari 2 tahun tersebut belum terpublikasi secara meluas. Ada beberapa jenis buku yang telah tersedia di kampong baca JASINDO, yang hampir keseluruhan buku-buku tersebut lebih mengarah ke pendidikan non formal, di antaranya buku novel, informasi, karya umum, kesusastraan, ilmu terapan, ilmu-ilmu murni, dan literatur anak. Berdasarkan keadaan tersebut, maka penulis berminat untuk meneliti dengan rumusan masalah sebagai berikut: 1) Bagaimana Kontribusi Kampung Baca Asuransi Jasindo dalam Memenuhi Kebutuhan Literasi Informasi Masyarakat Di Taman Sandik?, dan 2) Bagaimana kendala-kendala dalam Memenuhi Kebutuhan Literasi Informasi Masyarakat Di Taman Sandik?. Dengan tujuan penelitian ini yaitu; 1) Untuk mengetahui Bagaimana Kontribusi Kampung Baca Asuransi 
Jasindo dalam Memenuhi Kebutuhan Literasi Informasi Masyarakat Di Taman Sandik, dan 2)

Untuk mengetahui Bagaimana kendala-kendala dalam Memenuhi Kebutuhan Literasi Informasi Masyarakat Di Taman Sandik.

\section{METODE}

Metode yang digunakan dalam penelitian ini Metode kualitatif yaitu suatu prosedur penelitian yang menghasilkan data deskriptif berupa ucapan atau tulisan dan perilaku yang dapat diamati dari orang (subyek) itu sendiri. Selain itu, penelitian kualitatif adalah penelitian yang bermaksud untuk memahami fenomena tentang apa yang dipahami oleh subjek penelitian misalnya perilaku, persepsi, motivasi, tindakan, dll. Metode yang digunakan adalah metode kualitatif yaitu pengamatan, wawancara, atau penelaahan dokumen.

Dalam penelitian kualitatif yang menjadi instrumen atau alat penelitian adalah peneliti itu sendiri. Peneliti kualitatif berfungsi menetapkan fokus penelitian, memilih informan sebagai sumber data, melakukan pengumpulan data, menilai kualitas data, analisis data, menafsirkan data dan membuat kesimpulan atas temuannya. Objek penelitian yang digunakan adalah "Kontribusi Kampung Baca Asuransi Jasindo dalam Memenuhi Kebutuhan Literasi Informasi Masyarakat Di Taman Sandik”. Adapun ciri-ciri dari penelitian kualitatif adalah sebagai berikut:

a. Bersifat alamiah, penelitian kualitatif dilakukan pada latar alamiah atau konteks dari suatu keutuhan. Hal ini dilakukan karena sifat alamiah menghendaki adanya kenyataan-kenyataan sebagai keutuhan yang tidak dapat dipahami jika dipisahkan dari konteksnya.

b. Manusia sebagai alat (instrumen), dalam penelitian kualitatif, peneliti tersendiri atau dengan bantuan orang lain merupakan salah satu sarana pengumpulan data yang utama.

c. Metode kualitatif, metode yang digunakan yaitu pengamatan, wawancara, atau penelaahan dokumen,

d. Lebih mementingkan proses daripada hasil, hal ini disebabkan oleh adanya hubungan bagian-bagian yang sedang diteliti akan jauh lebih jelas apabila diamati dalam proses.

e. Jenis Penelitian

Penelitian ini bersifat deskriptif yang mempelajari masalah-masalah dalam masyarakat, serta tata cara yang berlaku dalam masyarakat serta situasi-situasi tertentu, termasuk tentang hubungan kegiatan-kegiatan, sikap-sikap dan pandangan- 
pandangan, serta proses-proses yang sedang berlangsung dan pengaruh-pengaruh dari suatu fenomena.

Metode deskriptif adalah penelitian yang diarahkan untuk memeberikan gejalagejala, fakta-fakta, atau kejadian-kejadian secara sistematis dan akurat. Tujuan dari penelitian deskriptif adalah untuk membuat deskrisi gambaran atau lukisan secara sistematis, faktual dan akurat mengenai fakta-fakta, sifat-sifat serta hubungan antar fenomena yang diselidiki.

Prosedur penelitian yang menghasilkan data deskriptif berupa kata-kata tertulis atau lisan dari orang-orang dan perilaku yang dapat diamati yang diarahkan pada latar dan individu tersebut secara holistic (utuh), sehingga dalam hal ini tidak boleh mengisolasikan individu atau organisasi ke dalam variabel atau hipotesis, tetapi perlu memandangnya sebagai bagian dari suatu keutuhan.

\section{HASIL DAN PEMBAHASAN}

\section{Kontribusi Kampung Baca Asuransi Jasindo dalam Memenuhi Kebutuhan Literasi Informasi Masyarakat Di Taman Sandik}

Keberadaan Kampung baca Asuransi Jasindo saat ini sangat penting peranannya bagi masyarakat Desa Sandik, mengingat di era saat ini perkembangan ilmu pengetahuan dan teknologi semakin meningkat dan menuntut masyarakatnya untuk bisa beradaptasi dengan perkembangan zaman yang selalu bergerak dinamis. Di sisi lain, Kampung Baca Asuransi Jasindo merupakan salah satu unsur penting untuk mendukung proses belajar mengajar setelah seseorang belajar disekolah atau bisa dikatakan sebagai unsur pendukung pendidikan formal. Tegasnya, keberadaan Kampung Baca Asuransi Jasindo di tengah-tengah kehidupan masyarakat diharapkan dapat membantu semua lapisan masyarakat dalam rangka mewujudkan masyarakat pembelajar sepanjang hayat yang memiliki budaya membaca dalam lingkungan sekolah, keluarga, dan masyarakat.

Dalam memenuhi kebutuhan informasi, perpustakaan tidak cukup hanya membangun jasa informasi, tetapi juga bagaimana informasi itu dapat diserap, disebarluaskan, dan dimanfaatkan secara efektif oleh masyarakat sebagai pengguna informasi atau pemustaka. Untuk efektifitas informasi itu perlu kiat atau cara dalam hal menarik minat masyarakat terhadap perpustakaan.

Menurut Kamus Besar Bahasa Indonesia, kontribusi diartikan sebagai "Sebagai uang iuran pada perkumpulan, sumbangan.” Dalam Undang-Undang Perpustakaan No 43 
Tahun 2007 Pasal 1 ayat 1 manyatakan Perpustakaan adalah institusi pengelola koleksi karya tulis, karya cetak, dan/atau karya rekam secara profesional dengan sistem yang baku guna memenuhi kebutuhan pendidikan, penelitian, pelestarian, informasi, dan rekreasi para pemustaka dan lain sebagainya.

Berikut beberapa kontribusi kampung baca asuransi jasindo dalam memenuhi kebutuhan literasi informasi masyarakat. Berdasarkan hasil wawancara yang telah dilakukan dengan Sekretaris Desa Sandik Muaidi sekaligus selaku penanggung jawab Kampung Baca Asuransi Jasindo menjelaskan:

"Awal mula berdirinya kampung baca Asuransi Jasindo melalui bantuan Bina Lingkungan PT. Asuransi Jasa Indonesia (Persero) Desa Sandik, Kecamatan Batulayar, Kabupaten Lombok Barat, Provinsi Nusa Tenggara Barat yang diresmikan pada bulan Mei 2019 oleh Direktur Keuangan Dan Investasi. Tekadnya untuk memberikan informasi kepada masyarakat sekitar sehingga memiliki kesadaran akan pentingnya literasi informasi. Kampung Baca Asuransi Jasindo menyediakan buku-buku yang ada, diharapkan dapat menjadi sumber belajar bagi masyarakat karena adanya buku yang ada di Kampung Baca Asuransi Jasindo dapat mendukung masyarakat mulai dari anak-anak hingga lansia untuk terus belajar, seperti buku pengetahuan untuk membuka wawasan bagi siswa, juga berbagai buku keterampilan praktis yang bisa dipraktekkan setelah membaca, ada praktek memasak dan praktek membuat kue bagi ibu-ibu, budidaya ikan, membuat pupuk organik, menanam berbagai jenis sayuran dan lainnya"

Pernyataan di atas menegaskan, jika Kampung Baca Asuransi Jasindo didirikan sebagai wadah sumber belajar dalam mengakses berbagai bahan bacaan untuk segala usia dan profesi, seperti buku pelajaran bagi siswa sekolah, buku keterampilan praktis bagi ibuibu, buku keagamaan, buku hiburan, buku pelatihan Life Skill bagi masyarakat luas, dan lain sebagainya. Dalam hal ini, Kampung Baca Asuransi Jasindo memfasilitasi dengan menyediakan buku yang beragam sehingga kebutuhan masyarakat akan ilmu pengetahuan sedikit bisa terpenuhi. Lebih lanjut terkait Kampung Baca Asuransi Jasindo sebagai sumber belajar, Sekretaris Desa Sandik Muaidi sekaligus selaku penanggung jawab menambahkan:

"Kita sebagai penanggungjawab sekaligus pengelola Kampung Baca Asuransi Jasindo memiliki beberapa kegiatan dalam hal pembelajaran. Dimana kegiatan itu dibuat disesuaikan dengan latar belakang profesi masyarakat yang bermacam-macam. Dalam memenuhi kebutuhan literasi informasi masayarakat, penanggungjawab Kampung Baca Asuransi Jasindo juga melakukan kegiatan kerjasama dengan pihak perpustakaan daerah Kabupaten Lombok Barat, PLN, dan Komunitas Baca baik yang berada di wilayah Lombok Barat maupun yang berada dari luar wilayah Lombok Barat. Tujuannya adalah untuk meningkatkan serta meng-Update jenis-jenis koleksi yang ada di Kampung Baca Asuransi 
Jasindo. Sehigga dengan adanya kegiatan kerjasama ini sangat membantu masyarakat sekitar untuk rekreasi literasi dan memenuhi kebutuhan informasi."

Terkait dengan Kampung Baca Asuransi Jasindo sebagai sumber literasi informasi juga dinyatakan oleh Mahidin selaku pengelola di Kampung Baca Asuransi Jasindo:

"Kampung Baca Asuransi Jasindo memiliki beberapa prestasi diantaranya adalah juara 1 tingkat Kabupaten Lombok Barat dalam pengelolaan Kampung Baca Asuransi Jasindo. Akses informasi yang ada di Kampung Baca Asuransi Jasindo juga bisa dilihat melalui media sosial baik itu melalui Facebook dan Instagram agar kaum milenial mengetahui segala jenis kegiatan yang ada di Kampung Baca Asuransi Jasindo.”

Kampung Baca Asuransi Jasindo seringkali diibaratkan sebagai perpustakaan area publik, dengan artian Kampung Baca Asuransi Jasindo merupakan Taman Baca masyarakat umum yang menyediakan berbagai sumber belajar, tempat bermain dan penyedia sumber informasi. Maka menjadi jelas, jika kontribusi Kampung Baca Asuransi Jasindo dalam mencerdaskan kehidupan masyarakat sangat strategis. Sebab fungsinya melayani semua lapisan masyarakat dalam rangka memperoleh dan meningkatkan berbagai ilmu pengetahuan. Kampung Baca Asuransi Jasindo memberikan layanan belajar kepada semua lapisan tanpa memandang status dan profesi, baik bagi anak-anak, remaja, dewasa, pelajar, mahasiswa, pegawai, ibu rumah tangga, para usia lanjut, lakilaki maupun perempuan.

\section{Kendala Dalam Memenuhi Kebutuhan Literasi Informasi Masyarakat Di Taman Sandik}

Berbicara tentang Kampung Baca Asuransi Jasindo ini disusun untuk memenuhi kebutuhan masyarakat akan sumber belajar dan informasi yang dekat dengan masyarakat. Kampung Baca Asuransi Jasindo ini juga diharapkan dapat memenuhi tuntutan pemerintah untuk membantu pemerintah dalam upaya meningkatkan literasi informasi dan budaya baca masyarakat.

1) Tempat Penyimpanan Kampung Baca Asuransi Jasindo

Kampung Baca Asuransi Jasindo adalah tempat atau ruang yang disediakan untuk menyimpan, memelihara, menggunakan koleksi buku, majalah, koran, dan bahan multimedia lain untuk dibaca, dipelajari, dibicarakan, dan dimanfaatkan oleh masyarakat secara perseorangan, kelompok atau kelembagaan. Pengertian ini menunjukan bahwa Kampung Baca Asuransi Jasindo sebisa mungkin mempunyai sarana prasarana yang memadai, Dari hasil penelitian yang menunjukan bahwa ada kendala pada ruang atau tempat untuk menyimpan buku ini menjadi salah satu faktor yang menjadikan suatu Kampung Baca Asuransi 
Jasindo kurang maksimal dalam penyelengaraan dan pengelolaanya. Tempat yang kurang luas menjadikan Taman Bacaan menjadi kelihatan kurang menarik hal bisa menjadi faktor kendala yang menyebabkan program tidak bisa optimal dalam meningkatkan minat baca. Hal ini perlu Solusi atau langkah kedepan untuk memaksimalkan penyelengaraanya. Agus M. Irhkam (2011:72) menyatakan bahwa Memaksimalkan ruang serta sarana prasarana Merupakan upaya untuk memperkuat dan meningkatkan mutu Taman Bacaan Masyarakat agar dapat Meningkatkan Meningkatkan minat baca masyarakat Dan Memperbanyak Berbagai Kegiatan Literasi Agar Dapat berfungsi baik bagi Masyarakat sedangkan dalam Pendidikan Nasional No. 48 Tahun 2010 penguatan dan perluasan adalah stimulan, artinya pancingan untuk budaya melalui penyediaan taman bacaan masyarakat, bahan bacaan memotivasi/mendorong dan mengajak masyarakat berpartisipasi aktif dan sumber informasi lain yang mudah, murah, dan merata serta sarana dalam pengembangan budaya baca melalui penyelenggaraan Kampung Baca Asuransi Jasindo. Pengertian ini menunjukan bahwa tempat memang penting bagi kegiatan dan tempat literasi, hal ini juga disadari betul oleh penyelenggara.

2) Tenaga Pustakawan

Untuk memelihara keberlangsungan penyelenggaraan Kampung Baca Asuransi Jasindo dan eksistensinya pada masyarakat diperlukan berbagai alternatif dalam pengelolaannya sehingga warga belajar dapat memanfaatkan Kampung Baca Asuransi Jasindo secara maksimal. Kampung Baca Asuransi Jasindo sebagai jantung pendidikan masyarakat di Desa Sandik, diharapkan mampu memotivasi dan menumbuh kembangkan literasi informasi dan kegemaran membaca bagi masyarakat melalui bahan bacaan dan sarana ruang baca yang disediakan pada area publik. Menurut Dalman (5:2014) Membaca merupakan suatu kegiatanatau proses kognitif yang berupaya untuk menemukan berbagai informasi yang terdapat dalam tulisan. Hal ini berarti membaca merupakan proses berfikir untuk memahami isi teks yang dibaca. Oleh sebab itu, membaca bukan hanya sekadar melihat kumpulan huruf yang telah membentuk kata, kelompok kata, kalimat, paragraf, dan wacana saja, tetapi lebih dari itu bahwa membaca merupakan kegitan memahami dan menginterpretasikan lambang atau tanda atau tulisan yang bermakna sehingga pesan yang disampaikan penulis dapat diterima oleh pembaca. Kegiatan membaca pula menjadikan seseorang akan terbentuk 
kepribadiannya menjadi lebih baik. Hal ini sesuai dengan Abdul Malik (2011:70) yang menyatakan dengan membaca kepribadian seseorang akan tumbuh kembang membaik ,karena dengan membaca mereka akan tau dan lebih terbuka akan wawan yang berdampak terhadap kebribadianya. Kepribadian adalah pola menyeluruh semua kemampuan, perbuatan serta kebiasaan seseorang, baik yang jasmani, mental, rohani, emosional maupun sosial. Dalam hal ini Taman bacaan dalam pengelolaan dan penyelengaraanya diprlukan suatu bentuk dampingan dari pihak penyelengara maupun instansi terkait. Hal ini tak lain dilakukan agar dalam perjalan Taman Bacaan Masyarakat bisa sesuai dan terarah sehingga dapat mencapai tujuan sesuai yang diharapkan yakni meningkatkan minat baca pada masyarakat. Minat dan kebutuhan masyarakat untuk gemar membaca memerlukan perhatian serius dari pemerintah, dari aktor pendidikan, dan dari pihak yang peduli pentingnya membaca. Salah yang diperlukan dalam Penyelengaran Kampung Baca Asuransi Jasindo adalah perhatian khusus dari penyelengara dan instansi dalam hal ini adalah adanya pendampingan. Pendampingan disini harapannya agar mampu dan menjadi salah satu perhatian pihak pemerintah akan meningkatkan sumber daya manusia melalui Kampung Baca Asuransi Jasindo karena dengan perhatian akan menjadikan minat akan membaca semakin baik dan kinerja pengelola menjadi baik pula. Wasti Sumanto (2001:7) berpendapat perhatian adalah pemusatan tenaga atau kekuatan jiwa tertentu kepada suatu obyek, atau pendayagunaan kesadaran untuk menyertai suatu aktivitas. Aktivitas yang disertai dengan perhatian intensif akan lebih sukses dan prestasinya pun akan lebih tinggi.

Keterangan yang dipaparkan diatas menjelaskan bahwa setiap program terutama Kampung Baca Asuransi Jasindo yang notabene adalah suatu model baru Kampung Baca Asuransi Jasindo pasti ada kendala yang menyertainya.

\section{PENUTUP}

\section{Simpulan}

Kontribusi Kampung Baca Asuransi Jasindo sebagai sumber belajar di Desa Sandik adalah menjadi wadah belajar yang berusaha menyediakan berbagai sumber belajar dan informasi, baik berupa bahan pustaka, novel, buku cerita rakyat dan bahan multimedia lainnya kepada masyarakat luas tanpa memandang status, usia, dan profesi. Hal ini 
dilakukan dalam rangka mewujudkan masyarakat pembelajar sepanjang hayat yang memiliki budaya literasi baik di dalam lingkungan sekolah, keluarga, dan masyarakat. Adapun bentuk-bentuk dari kontribusi Kampung Baca Asuransi Jasindo sebagai sumber belajar di Desa Sandik antara lain adalah membuat program "Literasi Informasi", dimana kegiatan tersebut berisi tentang kegiatan yang bersifat memperkenalkan masyarakat dalam menggunakan bahan bacaan yang ada di Kampung Baca Asuransi Jasindo. Selain itu, Kampung Baca Asuransi Jasindo juga menjadi tempat rekreasi edukatif yang diperuntukkan bagi anak-anak masyarakat di sekitarnya, bahkan adapun masyarakat yang datang dari luar Kabupaten Lombok Barat.

Kontribusi Kampung Baca Asuransi Jasindo sebagai sumber informasi adalah berusaha menyediakan bahan bacaan tertulis dan digital berupa akses internet yang dapat dipergunakan masyarakat untuk mencari berbagai informasi. Selain itu, Taman Baca Masyarakat sebagai sumber informasi adalah dengan mengadakan kegiatan bedah film yang sering diadakan di Kampung Baca Asuransi Jasindo. Dimana kegiatan tersebut diisi dengan menonton sebuah film bertema pendidikan pelatihan, sosial budaya dan lingkungan secara bersama-sama dan melakukan diskusi terkait film dan hubungannya dengan kehidupan sehari-hari. Manfaat yang bisa diambil dari bedah film ini yaitu para pengelola dapat memahami bahwa dalam sebuah film tersimpan banyak informasi, pesan, dan pengetahuan yang bisa diambil, baik itu kaitannya dengan kehidupan pendidikan, sosial budaya, politik, ekonomi, lingkungan, dan lain-lain. Dalam hal ini, Taman Baca Masyarakat menjadi daya pendukung untuk membantu masyarakat untuk mengumpulkan, mengolah, serta pengetahuan dan informasi.

Simpulan menyajikan ringkasan dari uraian mengenai hasil dan pembahasan, mengacu pada tujuan penelitian. Berdasarkan kedua hal tersebut dikembangkan pokok-pokok pikiran baru yang merupakan esensi dari temuan penelitian.

\section{DAFTAR PUSTAKA}

Dalman. 2014. “Keterampilan Membaca”. Jakarta: Rajawali Pers.

Laksmi. 2013. Tinjauan Kultural Terhadap Kepustakawanan: inspirasi dari sebuahkarya Umberto Eco. Depok: Fakultas Ilmu Pengetahuan Budaya.

Purwono. 2013. Profesi Pustakawan Menghadapi Tantangan Perubahan. Yogyakarta: Graha Ilmu.

Saleh, Adul Rahman. 2011. Percikan Pemikiran di Bidang Kepustakawanan. Jakarta: Sagung Seto. 
Suherman. 2011. Perpustakaan Sebagai Jantung Sekolah. Bandung: MQS Publishing.

Sudarsana, Undang. 2010. Materi pokok pembinaan minat baca. Jakarta: Universitas Terbuka.

Sugiyono. 2010. Metode Penelitian Kuantitatif Kualitatif dan R\&D. Bandung: Alfabeta.

Suwarno, Wiji. 2016. Library Life Style (trend dan Ide kepustakawanan) Yogyakarta: Lembaga Ladang Kata.

Makmur, Testiani. 2015. Budaya Kerja Pustakawan di Era Digitalisasi; Perspektif Organisasi, Relasi dan Individu. Yogyakarta: Graha Ilmu.

W. Gulo. 2010. Metodologi Penelitian. Jakarta: PT. Grasindo. 